\title{
Seasonal variation in biomass and species composition of seaweeds stranded along Port Okha, northwest coast of India
}

\author{
Mukund C Thakur, C R K Reddy and Bhavanath Jha* \\ Discipline of Marine Biotechnology \& Ecology, Central Salt $\&$ Marine Chemicals Research Institute (Council of \\ Scientific and Industrial Research), Gijubhai Badheka Marg, Bhavnagar 364 002, India. \\ e-mail: bjha@csmcri.org
}

Port Okha coast, which is known for its luxuriant growth of a diverse assemblage of seaweeds on Saurashtra coast, is found to have abundant quantities of seaweeds being drifted and washed ashore every year. Studies conducted for quantifying the stranded seaweeds from May 2004 to April 2005 showed an average biomass value of $3.10 \mathrm{~kg}$ fresh $\mathrm{wt} / \mathrm{m}^{2} / \mathrm{month}$ with maximum being $6.60 \mathrm{~kg}$ fresh $\mathrm{wt} / \mathrm{m}^{2}$ in April. The stranded weeds constituted a total of 62 species during the entire study period. Of this, Rhodophyta ranked high with 26 species followed by Chlorophyta with 22 species and Phaeophyta with 14 species. The stranded seaweeds that were washed ashore provide valuable floristic information about the intertidal and near shore sub-tidal algae of the respective regions. Although natural senescence of seaweeds is one of the major factors, strong currents primarily forced by tides, also contribute to the uprooting and subsequent drifting of seaweeds on to the beach. This ultimately causes changes in floristic features of the existing algal beds.

\section{Introduction}

About 8 million tons wet seaweeds are harvested annually worldwide and stranded seaweeds on the beach constitute a considerable part of it (McHugh 2003). The stranded seaweeds on the beach are harvested and utilized for a variety of purposes such as feed, fertilizer and as a source of raw material for industrial production of phytochemicals of commercial importance (Kirkman and Kendrick 1997). In Australia, harvesting of kelp drifts from beaches is a major activity and provides a sizable income for island communities. However, for an ordinary person these are huge piles of decaying plant material washed ashore above the high tide mark of the beach. It has also been earlier reported that the phycocolloid content of the drift seaweeds is comparable with that of those obtained from freshly harvested biomass (Krishnamurthy 1967). Further, the beach fauna such as Ligia pallasii, Traskorchestia traskiana and Megalorchestia californiana have also been found to prefer stranded seaweeds as their feed rather than fresh ones (Pennings et al 2000). The stranded seaweeds at the surf zone also provide a niche environment for juvenile fishes and wrack-inhabiting organisms (Lenanton et al 1982). The seabirds are often seen feeding on beachwrack. Accumulations of beach cast wreck are of immense ecological significance and contribute enormous quantities of organic matter which partly enters the trophic food chain and the remainder into the detrital pool either as particulate or dissolved organic matter in the ecosystem (Mitchell and Hunter 1970; Dooley 1972; Lenanton et al 1982; Robertson and Lenanton 1984; Safran and Omori 1990; Blanche 1992; Kirkman and Kendrick 1997).

Keywords. Abiotic factor; biomass; Port Okha; seasonal variation; stranded seaweeds. 


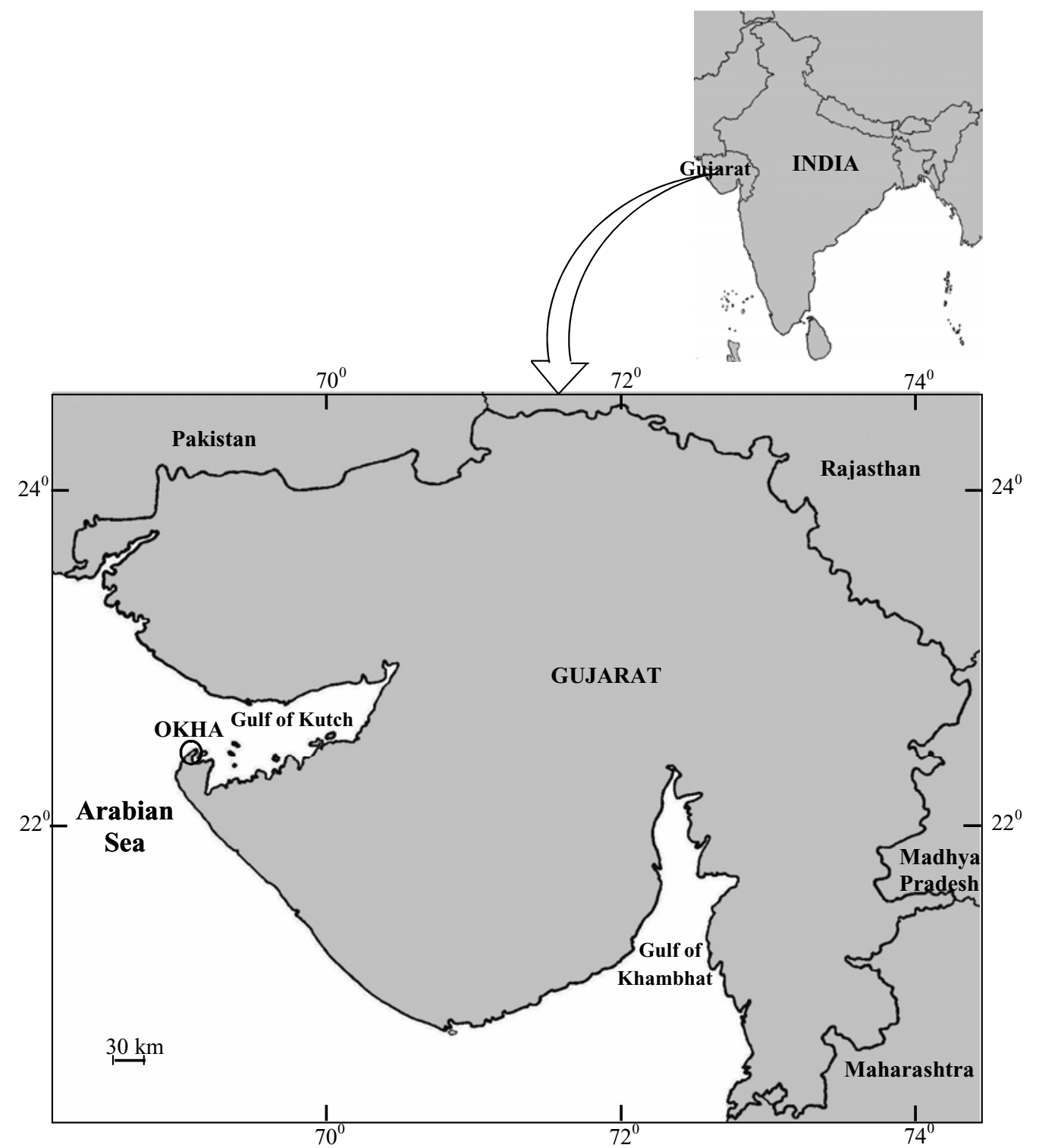

Figure 1. Map of India showing the study site of Port Okha.

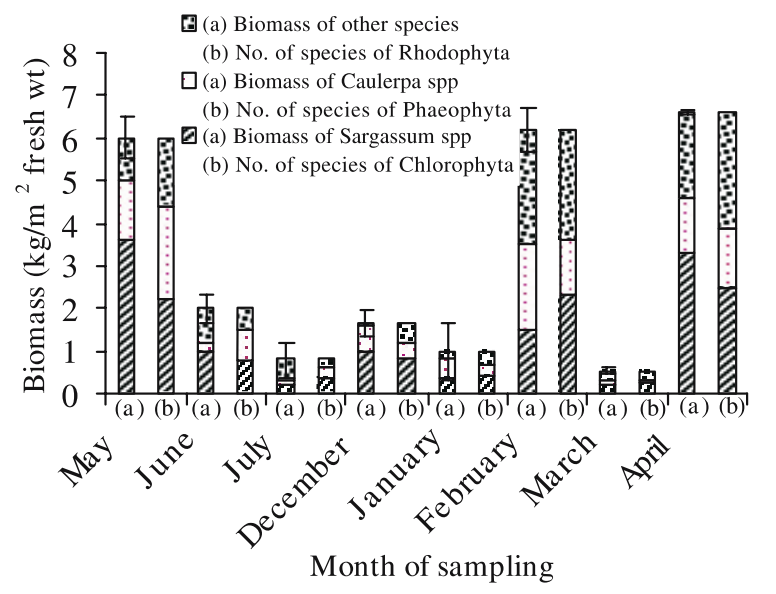

Figure 2. Biomass, species composition and dominant species of stranded seaweeds along Port Okha coast from May 2004 to April 2005.
Drifting of seaweeds has been reported from the Atlantic, Pacific and Indian Oceans and the Red Sea (Hirata et al 2003). In India, earlier studies have attempted to estimate drift seaweeds from selected parts of the Indian coasts (Mitra 1946; Krishnamurthy 1967). However, these studies are confined to estimate the most dominant species in the drift for a limited period. Initial efforts to estimate seaweed resources of the Indian coast were based on the weed washed ashore. Mantri and Chaugule (2005) reported ethanophycological use of drift seaweeds from the Maharashtra coast. In this paper, we report results of the systematic study undertaken to assess seasonal variation in biomass and species composition of stranded seaweeds together with causative factors that resulted in the drifting of seaweeds from May 2004 to April 2005 along the Port Okha coast. 


\section{Materials and methods}

\subsection{Study site}

Port Okha (lat. $22^{\circ} 28^{\prime} \mathrm{N}$ and long. $69^{\circ} 05^{\prime} \mathrm{E}$ ), situated at the mouth of "Gulf of Kutch" on the north-westernmost part of Saurashtra of Gujarat (figure 1) is one of the important places of interest for algal growth in the country (Mairh et al 1998). Physicochemical properties of seawater at Port Okha are as follows: temperature ranged from 21.5 to $30^{\circ} \mathrm{C}$, salinity from 35.46 to 37.32 PSU, D.O. from 5.3 to $6.7 \mathrm{ppm}$, turbidity from 0 to $200 \mathrm{ppm}$, phosphate phosphorus from 0.1 to $1.05 \mu \mathrm{g}$ atom/l, nitrate nitrogen from 2.0 to $11.5 \mu \mathrm{g}$ atom/1 (Chauhan 1965). This coast being at the mouth of "Gulf of Kutch" experiences strong water currents round the year as compared to other parts of the country. The coast is characterized by rocks made up of tertiary formations alternating with patches of sand deposits making the area more hospitable for the growth of all types of seaweed throughout the year (Børgesen 1934). Exposure of $0.7-0.9 \mathrm{~km}$ width of intertidal zone for $3-4$ hours with tidal amplitude of $4-5 \mathrm{~m}$ creates a unique habitat for luxuriant growth of diverse seaweeds (Misra 1960).

\subsection{Sampling}

Sampling was done from the uppermost littoral zone at monthly intervals from May 2004 to April 2005 over $500 \mathrm{~m}$ coastal stretch at Port Okha. During the months of August-November there was no drift available and hence no data collected. This season is generally considered as a cryptic or pre-regeneration stage for seaweed growth for this location (Chauhan 1965; Ohno and Mairh 1982). During sampling, the shorewashed seaweeds were collected by placing 5 random quadrates of $0.25 \mathrm{~m}^{2}$. The seaweeds which over-passed the edge of the quadrates were snapped with the help of a knife. The seaweeds thus harvested were separated species-wise, brought to the laboratory, washed and weighed for determining biomass. The data on species composition, abundance and biomass of stranded seaweeds for the entire study period are shown in the respective tables and figures.

\section{Results}

During the study period, stranded seaweeds constituted a total of 62 species (table 1 ). The diversity of the species in stranded seaweeds showed a declining trend from the month of June onwards. Although biomass values of stranded seaweeds varied with the month, the highest biomass values recorded for the months of February, April and May ranged between 6.0 and $6.6 \mathrm{~kg}$ fresh $\mathrm{wt} / \mathrm{m}^{2}$. The lowest biomass being $0.55 \mathrm{~kg}$ fresh $\mathrm{wt} / \mathrm{m}^{2}$ collected in March (figure 2). The total biomass of the stranded seaweeds during the entire study period ( 8 months) was $24.82 \mathrm{~kg}$ fresh wt $/ \mathrm{m}^{2}$ with the average being $3.1 \mathrm{~kg}$ fresh $\mathrm{wt} / \mathrm{m}^{2}$. Indeed, a major part of the stranded seaweed is represented by species of Rhodophyceae with 26 , followed by Chlorophyceae with 22, and Phaeophyceae with 14 . The seaweeds collected in December 2004 and February 2005 contained maximum diversity with as many as 29 species, and a minimum of 12 was in July 2004. However, Sargassum (Phaeophyceae) and Caulerpa (Chlorophyceae) are the two conspicuous partners that formed the major part of beach-stranded seaweeds throughout the study period (figure 2).

\section{Discussion}

The biomass as well as species composition of stranded seaweeds largely depend upon season, population structure and several other ecological factors (Krishnamurthy 1967). Further, the vegetation cover, age and height of individual plants, morphology and structure of thallus also contribute to the drifting of seaweeds (Norton et al 1982). The biomass of seaweed drifted to the coast can be correlated with the abiotic factors that prevailed before or during the collection period (McQuaid 1985). When the seaweeds get detached from its natural habitat due to any reason, it could be washed ashore forming the stranded seaweeds at the beach.

It is evident from data that the maximum drift of seaweeds occurred during February, April and May which is generally considered as a peak growth period for many types of seaweed on the Okha coast. Seaweeds as compared to other marine plants are short-lived with successive growth periods and more than two growth peaks during their life span when the season is conducive. The lowest values obtained during March could be attributable to an intermittent period in which some seaweed populations rejuvenate and recover from wholesome detachment. The seasonal variation in species composition of stranded seaweeds in the present study is correlated with species succession in the natural seaweed habitat of Port Okha coast (Murthy et al 1978). The seaweed growth season on Okha coast is spread over to seven months beginning from November to May. During this period, the coast witnesses extensive growth and succession of different types of seaweed. The monsoon period (June-September) is a lean period 
Table 1. Species abundance of drift seaweeds along the Port Okha coast from May 2004 to April 2005.

Months

Species May June July December January February March April

\section{Chlorophyta}

Acrosiphonia orientalis (J. Agardh)

P. Silva, com. nov.

Boodlea composita (Harvey) Brand

Bryopsis plumosa (Hudson) C. Agardh

Caulerpa racemosa (Forsskål) J. Agardh

var. macrophysa (Sonder ex Kützing)

W. R. Taylor

C. scalpelliformis (R. Brown ex Turner)

C. Agardh

C. sertularioides (S. Gmelin) Howe

C. taxifolia (Vahl) C. Agardh

C. veravalensis Thivy \& Chauhan

C. verticillata J. Agardh

Chaetomorpha crassa (C. Agardh) Kutzing

C. spiralis Okamura

Codium elongatum Børgesen

Dictyospheria cavernosa (Forsskål)

Børgesen

Enteromorpha compressa (Linn) Nees

E. intestinalis (Linn) Nees

Halimeda tuna (Ellis \& Solander)

Lamouroux

Struvea anastomosans (Harvey) Piccone \& Grunow ex Piccone

Ulva fasciata Delile

U. lactuca Linnaeus

Udotea flabellum (Eliss \& Solander)

U. indica A. Gepp \& E. Gepp

Valoniopsis pachynema (G. Martens)

Børgesen

\section{Phaeophyta}

Colpomenia sinuosa (Merens ex Rotyh)

Derbes \& Solier

Cystoseira indica (Thivy \& Doshi) Mairh

C. trinodis (Forsskal) C. Agardh

Dictyopteris australis (Sonder) Askenasy

Dictyota dichotoma (Hudson) Lamouroux

Dilophus sp. J. G. Agardh

Iyengarii stellata (Børgesen) Børgesen

Lobophora variegata (Lamouroux)

Womersley ex Oliveria

Padina tetrastromatica Hauck

Sargassum swartzii C. Agardh

S. tenerrimum J. Agardh

Spatoglossum asperum J. Agardh

S. variabile Figari \& De Notaris

Stoechospermum marginatum (C. Agardh)

$\begin{array}{cccc}- & +++ & - & - \\ - & - & - & ++ \\ +++ & + & + & - \\ +++ & - & - & ++\end{array}$

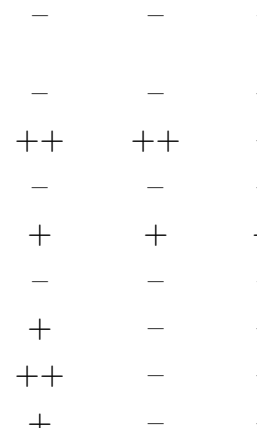

$\begin{array}{lll}- & + & +\end{array}$

$++$

$+++$

$+$

$-$

$+++$

$++$

$++$

$-$

$+$

$-$

$-$

$++$

$-$

$+$

$\begin{array}{ccccc}- & - & - & & \\ - & - & - & - & +\end{array}$

$\begin{array}{llllll}- & - & - & - & & +\end{array}$

$++\quad++\quad-\quad+$

$+$

$\begin{array}{llll}- & - & -\end{array}$

$\begin{array}{lll}+ & - & +\end{array}$

$\begin{array}{cccc}- & - & ++ & ++ \\ +++ & - & + & ++ \\ - & - & ++ & - \\ - & - & + & + \\ ++ & ++ & - & +\end{array}$

$++$

$++$

\begin{tabular}{|c|c|c|c|c|c|c|c|}
\hline++ & - & - & ++ & - & - & - & ++ \\
\hline++ & ++ & - & - & + & - & - & ++ \\
\hline+ & - & - & - & - & - & - & + \\
\hline- & - & - & - & - & +++ & - & - \\
\hline++ & - & - & - & - & ++ & - & - \\
\hline+ & - & - & + & - & - & - & - \\
\hline- & - & - & +++ & ++ & ++ & - & - \\
\hline- & + & - & - & - & - & - & - \\
\hline++ & ++ & ++ & ++ & - & + & - & - \\
\hline+++ & + & - & ++ & + & - & ++ & +++ \\
\hline++ & +++ & ++ & + & ++ & ++ & + & +++ \\
\hline+ & - & + & ++ & - & ++ & - & - \\
\hline- & + & - & - & - & - & - & - \\
\hline++ & - & - & - & - & - & - & - \\
\hline
\end{tabular}


Table 1. (Continued)

\begin{tabular}{|c|c|c|c|c|c|c|c|c|}
\hline \multirow[b]{2}{*}{ Species } & \multicolumn{8}{|c|}{ Months } \\
\hline & May & June & July & December & January & February & March & April \\
\hline \multicolumn{9}{|l|}{ Rhodophyta } \\
\hline $\begin{array}{l}\text { Agardhiella subulata (C. Agardh) Kraft \& } \\
\text { Wynne }\end{array}$ & + & - & - & + & - & - & - & - \\
\hline Amphiroa anceps (Lamarck) Decaisne & + & ++ & ++ & + & + & - & - & - \\
\hline Asparagopsis taxiformis (Delile) Trevisan & - & - & - & - & - & - & - & ++ \\
\hline Botryocladia botryoides J. Agardh & ++ & + & + & - & - & - & - & - \\
\hline Ceramium rubrum Auctorum & - & + & - & + & - & - & - & + \\
\hline Champia globulifera Børgesen & - & - & - & - & - & ++ & - & - \\
\hline $\begin{array}{l}\text { Chondria dasyphilla (Woodward) } \\
\text { J. Agardh }\end{array}$ & - & - & - & - & - & + & - & ++ \\
\hline Coelarthrum muelleri (Sonder) Børgesen & - & - & - & - & - & ++ & + & + \\
\hline $\begin{array}{l}\text { Corynomorpha prismatica (J. Agardh) } \\
\text { J. Agardh }\end{array}$ & + & ++ & - & - & - & - & - & - \\
\hline Cryptonemia undulata Sonder & - & - & - & - & - & - & - & + \\
\hline Gracilaria verrucosa (Hudson) Papenfuss & - & - & - & + & + & - & - & + \\
\hline Grateloupia indica Børgesen & - & - & - & - & - & + & ++ & + \\
\hline $\begin{array}{l}\text { Griffithsia rhizophora Frunow ex Weber - } \\
\text { van Bosse }\end{array}$ & - & - & - & - & - & +++ & ++ & - \\
\hline Halymenia venusta Børgesen & ++ & - & - & + & - & ++ & +++ & ++ \\
\hline Heterosiphonia muelleri (Sonder) De Toni & - & - & - & +++ & +++ & - & - & - \\
\hline Hypnea musciformis (Wulfen) Lamouroux & - & - & - & - & + & +++ & - & +++ \\
\hline $\begin{array}{l}\text { Hypoglossum heterocystideum (J. Agardh) } \\
\text { J. Agardh }\end{array}$ & - & - & - & - & - & - & +++ & - \\
\hline Jania rubens (Linnaeus) Lamouroux & - & - & - & - & - & - & - & + \\
\hline $\begin{array}{l}\text { Leveillea jungermannioides (Hearing \& } \\
\text { G. Martens) Harvey }\end{array}$ & - & - & - & + & - & - & + & - \\
\hline $\begin{array}{l}\text { Lophocladia lallemandi (Montagne) } \\
\text { Schmitz }\end{array}$ & - & - & - & - & - & + & - & - \\
\hline Polysiphonia platycarpa Børgesen & - & - & - & - & + & + & - & - \\
\hline Predaea feldmanni Børgesen & - & - & - & - & - & & & ++ \\
\hline Sarconema scinaioides Børgesen & + & - & - & ++ & ++ & + & - & - \\
\hline Scinaia hatei J. Agardh & ++ & - & - & - & - & ++ & - & - \\
\hline Scinaia monoliformis J. Agardh & - & - & - & - & - & +++ & - & - \\
\hline Solieria robusta (Greville) Kylin & - & - & - & - & - & - & +++ & - \\
\hline
\end{tabular}

+++ dominant; ++ average; + meager and - absent.

Table 2. Wind velocity (24 hours) at Port Okha during the study period.

\begin{tabular}{lccccccc}
\hline \multirow{2}{*}{$\begin{array}{c}\text { Date and time of } \\
\text { sampling }\end{array}$} & $\begin{array}{c}\text { Wind } \\
\text { direction }\end{array}$ & $4 \mathrm{~h}$ & $8 \mathrm{~h}$ & $12 \mathrm{~h}$ & $16 \mathrm{~h}$ & $20 \mathrm{~h}$ & $24 \mathrm{~h}$ \\
\cline { 3 - 7 } May 2004 & $\mathrm{SW}$ & 1 & 1 & 1 & 1 & 1 & 1 \\
June 2004 & $\mathrm{SW}$ & 3 & 3 & 3 & 3 & 3 & 3 \\
July 2004 & $\mathrm{SW}$ & 1 & 1 & 1 & 1 & 1 & 1 \\
December 2005 & $\mathrm{NE}$ & 2 & 2 & 2 & 3 & 3 & 2 \\
January 2005 & $\mathrm{SE}$ & 3 & 2 & 2 & 2 & 2 & 3 \\
February 2005 & $\mathrm{NE}$ & 1 & 1 & 1 & 1 & 1 & 1 \\
March 2005 & $\mathrm{SE}$ & 1 & 1 & 1 & 1 & 1 & 1 \\
April 2005 & $\mathrm{SW}$ & 2 & 2 & 1 & 1 & 2 & 2 \\
\hline
\end{tabular}

${ }^{*} 1=18.52-27.78 \mathrm{~km} / \mathrm{h}, 2=27.78-37.04 \mathrm{~km} / \mathrm{h}, 3=37.04-46.30 \mathrm{~km} / \mathrm{h}$

(Source: Coast Guard Station, Okha Port, Okha). 
supporting scanty growth of a few species confined to supra littoral zone.

Therefore, the extensive drifting of seaweeds always occurs during the tail end of the seaweed growth period. This is the period many seaweeds attain senescence and any wave action with moderate force together with changes in seawater temperature, uproot the plants causing floating and stranding to the beach. The observed wind speed at Port Okha during this period varied from 18.5 to $46.3 \mathrm{~km}$ /hour (table 2; A Das, personal communication 2007) and water currents at Port Okha range from 1.5 to $2 \mathrm{~m} / \mathrm{s}$ (Capt. R K Raman, personal communication 2007). The observed winds are unable to generate strong enough local currents, but there are two other processes that are important. The strongest currents around Port Okha are associated with the tides, which force currents as strong as 1-2 m/s (Unnikrishnan and Luick 2003), comparable to the currents observed in the region. An additional contribution comes from the large-scale wind-forced circulation, which is associated with monthly-mean current speeds of about $0.5 \mathrm{~m} / \mathrm{s}$ during May (Mariano et al 1995; Shankar et al 2002). The resultant current speeds in excess of $2 \mathrm{~m} / \mathrm{s}$ can cause uprooting of the seaweeds. Water velocities causing uprooting of seaweeds in seaweed zone have also been reported by Jones and Demetropoulos (1968).

Since the study site at Port Okha is a protected and sheltered bay, the seaweed biomass from nearby places and upstream areas gets concentrated in this region and piles-up on the beach as a result of wave action. The size of the drift or stranded seaweed is indicative of the existence of algal beds in coastal waters. The greater the drift the larger the algal community in existance. There is no any definite pattern in the species composition of stranded seaweed. However, the clear-cut dominance of members of Chlorophyceae could be attributed to the simple paranchymatous nature of the fronds. Moreover, the entire algal thallus is exposed to motion, unlike a land plant in which the anchoring roots are beneath the soil and out of the wind. This kind of wave action may hardly be tolerated by the Chlorophycean members with soft thallus. However, the Rhodophycean members, which tend to drift, are mostly of cartilaginous and fragile causing breaking of thallus. Sargassum and Caulerpa are the two taxa that contributed to maximum stranded seaweed biomass. This could be due to the branched, anastomizing habit of fronds, resulting into extensive spread in the intertidal area as compared to other seaweed species. Krishnamurthy (1967) found that the seaweeds washed ashore during November and December were very less but abruptly increased in January.
The Sargassum was the major constituent in the drift while only a small amount (less than $1 \%$ ) was contributed by the other alga. In the present study, the seaweeds stranded ashore were negligible during December and January but suddenly increased by a factor of 6 times in February. The life history and phenology of Sargassum species and its recruitment dynamics have extensively been investigated (Chauhan and Krishnamurthy 1967a, 1967b; Raju and Venugopal 1971; Chauhan 1972; Chauhan and Mairh 1978; Kendrick 1994; Kendrick and Walker 1995). Sargassum species are canopy-forming algae up to $120 \mathrm{~cm}$ tall; and commonly grow in semiexposed habitats from the intertidal to subtidal reefs (up to $30 \mathrm{~m}$ depths) in tropical and temperate regions (Chauhan 1972; Kirkman and Kendrick 1997). The Sargassum forest plays an important role in marine ecosystem. The commercially important fish spawn, abalone and turban shells are usually found to inhabit the Sargassum forest (Komatsu et al 2007). The drifted and floating fronds of Sargassum provide the habitat for juvenile fishes (Lenanton et al 1982) and provide a base for the food chain for pelagic seabirds. Most of the species of Sargassum occurring on the Gujarat coast complete their life cycle in the months of November-December and May-June and later get detached from their natural habitat due to senescence.

Caulerpa Lamouroux is a highly polymorphic genus belonging to the family Caulerpaceae inhabiting in warm waters (Silva 2002). The monographic account on the Caulerpa species in India has been described by Duraiswamy $(1989,1990$ a and b). The Caulerpa species are normally $0.75 \mathrm{~mm}$ (Caulerpa verticillata) to $185 \mathrm{~mm}$ (Caulerpa taxifolia) tall and grow as creepers on rocks (e.g. C. microphysa), in pools (e.g. C. recemosa var. occidentalis), on sandy patches of middle and lower intertidal regions (e.g. C. sertularioides), on submerged subtidal rocks (e.g. C. taxifolia) and on muddy upper littoral zones (e.g. C. verticillata) (Mantri et al 2004). Most intertidal plants experience desiccation and water abrasion and many of the seaweeds uprooted by wave abrasion are cast on nearby shores. Moreover, the forms present in the drift are not hydro dynamically strong and transmit all wave exerted pressure on their holdfast leading to rapid dislodgement. On the contrary, some seaweed species like Gelidiella and Gelidiopsis are relatively small in size but have a very strong anchoring system that enables them to withstand wave action and prevent them from dislodgement and subsequent drifting even during rough sea conditions.

The stranded seaweeds that are washed ashore provide valuable floristic information about the respective intertidal and near shore sub-tidal 
regions. The stranding of seaweeds along the coastline is not only due to the function of natural senescence and death but also due to uprooting by the heavy winds and water currents often occurring in the coastal regions. This ultimately causes changes in floristic features of the existing algal beds.

\section{Acknowledgements}

We would like to thank Dr. Pushpito Kumar Ghosh, Director, for encouragement, Mr. A Das, Asst. Comndt, CGS, Port Okha for providing wind velocity data and Capt. R K Raman, Port Officer, Okha for seawater current data used in the present study. The authors would like to thank Dr. D Shankar, Associate Editor, Journal of Earth System Science, for valuable suggestions on the manuscript. The first author (MCT) wishes to thank GSBTM, State Govt. of Gujarat for Research Associateship.

\section{References}

Blanche K R 1992 Preliminary observations on the distribution and abundance of seaweed flies (Diptera: Coelopidae) on beaches in the Gosford district of New South Wales, Australia; Aus. J. Ecol. 17 27-34.

Børgesen F 1934 Some marine algae from the northern part of the Arabian Sea with remarks on their geographical distribution; Kongelige Danske Videndkabernes Selskab; Biologiske Meddelelser. 1172 pp.

Chauhan V D 1965 Some observations of chemical and physical conditions of seawater at Port Okha; Proceedings of the seminar on sea, salt and plants, Bhavnagar; 41-45.

Chauhan V D 1972 Physiological ecology of the early stages of Sargassum swartzii (Turner) C. Ag.; Bot. Mar. 15 49-51.

Chauhan V D and Krishnamurthy V 1967a Observations on the output of zoospores, their liberation, viability and germination in Sargassum swartzii (Turner) C. Ag.; Proceedings of the seminar on sea salt and plants, CSMCRI, Bhavnagar, pp. 197-201.

Chauhan V D and Krishnamurthy V 1967b Ecology and seasonal succession of Sargassum swartzii (Turner) C. Ag. in Indian waters; Phykos 10 1-11.

Chauhan V D and Mairh O P 1978 Report on the survey of marine algae resources of Saurashtra coast; Salt Res. India 14(2) 21-41.

Dooley J K 1972 Fishes associated with the pelagic Sargassum complex, with a discussion of the Sargassum community; Contrib. Mar. Sci. 16 1-32.

Duraiswamy R 1989 Studies on Caulerpa Lamouroux from India I; Seaweed Res. Util. 11 83-106.

Duraiswamy R 1990a Studies on Caulerpa Lamouroux from India II; Seaweed Res. Util. 12 55-86.

Duraiswamy R 1990b Studies on Caulerpa Lamouroux from India II; Seaweed Res. Util. 13 29-76.

Hirata T, Tanaka J, Iwami T, Ohmi T, Dazai A, Aoki M, Ueda H, Tsuchiyam Y, Sato T and Yokohama Y 2003 Ecological studies on the community of drifting seaweeds in the south-eastern coastal waters of Izu Peninsula, central Japan. II: Seasonal changes in plants showing maximum stipe length in drifting seaweed communities; Phycol. Res. 51 186-191.
Jones W E and Demetropoulos A 1968 Exposure to wave action: Measurements of an important ecological parameter on rocky shores of Anglesey; J. Exp. Mar. Biol. Ecol. 2 46-48.

Kendrick G A 1994 Effects of settlement density and adult canopy on survival of recruits of Sargassum spp. (Sargassaceae phaeophyta); Mar. Ecol. Progr. Ser. 103 129-140.

Kendrick G A and Walker D I 1995 Dispersal of propagules of Sargassum spp. (Sargassaceae phaeophyta): observations of local patterns of dispersal and possible cosequences for recruitment and population structure; J. Exp. Mar. Biol. Ecol. 192 273-288.

Kirkman H and Kendrick G A 1997 Ecological significance and commercial harvesting of drifting and beachcast macroalgae and seagrasses in Australia: A review; J. Appl. Phycol. 9 311-326.

Komatsu T, Matsunaga D, Mikami A, Sagawa T, Boisnier E, Tatsukawa K, Aoki Masakazu, Ajisaka T, Uwai S, Tanaka K, Ishida K, Tanoue H and Sugimoto T 2007 Abundance of drifting seaweeds in eastern East China Sea; J. Appl. Phycol. DOI 10.1007/s10811-0079302-4.

Krishnamurthy V 1967 Seaweed drift on the Indian coast. Proceedings of the Symposium "Indian Ocean"; Bull. Nat. Inst. Sci. India 38 657-666.

Lenanton R C J, Robertson A I and Hansen J A 1982 Nearshore accumulations of detached macrophytes as nursery areas for fish; Mar. Ecol. Prog. Series 9 $51-57$.

Mairh O P, Reddy C R K and Raja Krishnakumar G 1998 The seaweed resources of India. In: Seaweed Resources of the World; (eds) A T Critchely and M Ohno, Publication of Japanese International Cooperation Agency, Yokosuka, pp. $110-126$.

Mantri V A and Chaugule B B 2005 A less known ethanophycological use of seaweeds of Malvan; Indian Hydrobiol. 8 147-150.

Mantri V A, Joshi H V and Zaidi S H 2004 Seaweeds of Samiani Island - II Family: Caulerpaceae (Chlorophyta); Seaweed Res. Util. 26(1 \& 2) 231-236.

Mariano A J, Ryan E H, Perkins B D and Smithers S 1995 The Mariano Global Surface Velocity Analysis 1.0; USCG Report CG-D-34-95, 55 pp.

McHugh D J 2003 A guide to the seaweed industry; FAO Fisheries Technical Paper 441105 pp.

McQuaid C D 1985 Seasonal variation in biomass and zonation of nine intertidal algae in relation to changes in radiation, sea temperature and tidal regime; Bot. Mar. 28 $539-544$.

Misra J N 1960 The ecology, distribution and seaweed succession of the littoral algae on the west coast of India; In Proceeding Symposium on Algology (ed.) P Kachiroo, ICAR, New Delhi, pp. 187-203.

Mitra C 1946 Report on Development of Chilka Lake, Orissa Govt. Press, Cuttack, 1-26 pp.

Mitchell C T and Hunter J R 1970 Fishes associated with drifting kelp, Macrocystis pyrifera, off the coast of southern California and northern Baja California; Calif. Fish Game 56 288-297.

Murthy M S, Bhattacharya M and Radia P 1978 Ecological studies on the intertidal algae at Okha (India); Bot. Mar. 21 381-386.

Norton A C, Mathieson A C and Neushul M 1982 A review of some aspects of form and function in seaweeds; Bot. Mar. 25 501-510.

Ohno M and Mairh O P 1982 Ecology of green algae Ulvaceae occurring on the coast of Okha, India; Reports of the USA Mar. Biol. Inst. 4 1-8. 
Pennings S C, Thomas H, Zimmer C M, Danko J P and Ziegler A 2000 Feeding preferences of supralittoral isopods and amphipods; Can. J. Zool. 78(11) 1918-1929.

Raju P V and Venugopal R 1971 Appearance and growth of Sargassum plagiophyllum (Mart) C. Ag. on a fresh substratum; Bot. Mar. 14(1) 36-38.

Robertson A L and Lenanton R C J 1984 Fish community structure and food chain dynamics in the surfzone of sandy beaches: The role of detached macrophyte detritus; J. Exp. Mar. Biol. Ecol. 84 265-283.
Safran P and Omori M 1990 Some ecological observations on fishes associated with drifting seaweed off Tohoku coast; Mar. Biol. 105 395-402.

Shankar D, Vinayachandran P N and Unnikrishnan A S 2002 The monsoon currents in the North Indian Ocean; Progr. Oceanogr. 52 63-120.

Silva P C 2002 International Caulerpa taxifolia conference; www.sgnis.org.

Unnikrishnan A S and Luick J L 2003 A finite element simulation of tidal circulation in the Gulf of Kutch, India, Estuar. Coast. Shelf Sci. 56 131-138. 